RENEE PERELMUTTER

\title{
CASE CHOICE IN RUSSIAN GENITIVE/NOMINATIVE ABSENCE CONSTRUCTIONS*
}

\author{
Running Title: Gen/Nom Absence Constructions
}

\section{$\underline{\text { 1. Introduction }}$}

Negated be sentences with an animate referential subject have two morphological realizations in Modern Russian. The more statistically frequent construction has a referential subject of the negated clause in the genitive case: $\mathrm{SUBJ}_{\mathrm{gen}}+$ He было + locus: мамы не было на работе. In the less common construction the subject of the negated clause appears in the nominative case: $\mathrm{SUBJ}_{\text {nom }}+$ не был/a + locus: мама не была на работе. A question to ask then is, how does the speaker make the choice between these two constructions, and what are the factors influencing the choice.

First of all, this choice is only possible for an animated referential subject; nonanimated subjects in negated be clauses are always marked genitive: дома не было молока. Thus, the discussion of choice in negated be clauses will necessarily involve at least one individual. I label the negated be clauses with an animated subject ABSENCE clauses, to distinguish them from other negated be clauses that do not allow the choice of case. 
The choice between the genitive/nominative absence clauses is usually discussed in the larger context of verbs that allow a choice between genitive and nominative marking for the referential subject under negation. There exists a large body of literature debating the differences between the choice of genitive and the nominative, and the terminology in which to discuss them ${ }^{\dagger}$. In some studies, primary importance is assigned to distinguishing existential negated clauses versus other types of negated clauses. Babby (1980), for example, introduced the terms "negated declarative sentences" for the nominative construction, and "negated existential sentences" for the genitive construction. Babby proposed that the scope of negation is different for declarative versus existential constructions: in existential sentences, both the subject and the verb fall under the scope of negation; in declarative constructions, the subject is outside the scope of negation. Babby describes sentences of the tyре мамы не было на работе as "locative", a subtype of a negated declarative sentence, and not "existential", since, unlike the negated existential sentences, this type of sentence allows for a definite subject. Borschev and Partee (1998a; 2002) argue that these "locative" быть sentences can be interpreted as existential, since existence is always relevant to a locus; according to this analysis, быть sentences are existential.

Paducheva examined the choice of genitive/nominative specifically in быть sentences in her groundbreaking article of 1992; later (1997) she expanded the discussion to include other verbs that allow the choice of case. Paducheva divides the verbs that allow the genitive referential subject (which she calls genitive verbs) into two groups: 
perceptual and existential. Her insightful proposal was that the semantics of perceptual verbs, among them быть, presupposes a perceiving entity (OBSERVER, наблюдатель) that shares the locus with the referential subject. According to Paducheva's analysis, the genitive construction presupposes an observer who is synchronous with the individual in the locus; she concludes that the nominative clause presupposes an observer as well, but the nominative observer is "retrospective". That is, the observer is observing the whole utterance situation.

Borschev and Partee (2002) elaborate on Paducheva's notion of observer. They propose that the distinction between existing and being located involves a choice of perspective, a point of view of the speaker, or sometimes the subject of a higher clause in the sentence: "The speaker, of course, is the one who chooses the form of expression; but if the relevant clause is an embedded one, the speaker may be representing the point of view of a higher subject of a propositional attitude. And even in the case of a simple sentence, if it occurs as a part of a narrative, then the point of view of someone other than the "author" may be represented" (Borschev and Partee 2002: 208).

Timberlake (2004) talks about predicates which discuss the presence of an entity in a domain, either a physical space or a speaker's perceptual field. The nominative construction is used for a statement which focuses on the individual and his/her properties, and the genitive construction is used when a statement is made about the world and its contents: 
"In principle such combinations can be interpreted in two different ways: as a statement about an individual or as a statement about a world and its contents. In the former case, interest is focused on the individual, who is otherwise known, and on the properties of that individual. In the latter case, the communicative force of the sentence is merely to establish or deny the presence of some entity in some domain, the entity often being understood as an essence. When such predicates of location are negated, the entity whose existence is negated appears in the genitive" (Timberlake 2004, 311).

Chvany $(1996,91)$ discusses the genitive/nominative in быть sentences in terms of markedness and focusing. She discusses the pair, (a) Боб не был в Бостонеl (b) Боба в Бостоне не было:

(a) "is a statement about a foregrounded Bob, translatable as "Bob has not been in Boston", or "Bob did not go to Boston", or "Bob did not show up" - a volitional connotation is possible. ... The sentence is used appropriately only if the speaker is correct in assuming that Bob was in a position to make a choice...- that is, to take responsibility, exert some control. In contrast, (b) is a statement about Bob's absence from some event in Boston, whatever it was, which is foregrounded from the speaker's point of view, whence the word order change

Chvany argues that genitive can signal discourse backgrounding of an actant, and that this backgrounding can appear even in isolated sentence contexts. Nominative signals foregrounding, in opposition to the oblique cases. Later in the same volume (Chvany 
1996, 290) Chvany discusses the pair of clauses: Иван не был в Москве/Ивана не было в Москве. She emphasizes that the genitive is more contextual than nominative; a genitive быть sentence is a statement about absence from a foregrounded event: "A well-formed instance of (nom) requires only the givenness of Ivan and Moscow; but the felicitous use of (gen) requires additional information about what was going on in Moscow".

The above analyses reveal interesting and valid points about the genitive/nominative constructions. Chvany's insightful discussion of genitive clauses being associated with a foregrounded event is largely supported by my data. Paducheva's innovative approach, and Borschev and Partee's mention of possible involvement of the higher clause in the sentence, point to the necessity of looking beyond the negated clause, to search for other elements or entities which influence this clause and form cohesive connections with it. However, these studies tend to emphasize a single binary distinction that leads to a choice of case.

The approach taken here differs mainly in its multifactor approach to choice; I show that case choice cannot be reduced to a single factor, such as observer, foregrounding etc. Rather, the choice of genitive or nominative case in absence constructions routinely involves a number of factors coming together. These factors are not symmetrical and operate on different linguistic levels (the clause, the text) and involve not only structural elements, but emotional attitude, point of view, etc. No single 
factor can account for all instances in which a choice of case is made; a combination of possible factors prompts case choice.

It becomes apparent that both genitive and nominative clauses routinely belong to a number of fixed semantic templates (such as lack of information, making excuses, missing an event of death, etc). Many instances of the use of the absence constructions fit these templates. However, for those situations that do not fit the templates, the speaker is free to create meaningful clauses, as long as other factors (coordination, type of locus, etc) are still congruent with the implications of a given choice.

Table 1 summarizes the factors that influence the choice of case. The first three factors are structural and relevant to the clause; next three are text-level structural elements; following are emotional attitude and point of view. The last group summarizes the common semantic templates. 
Table 1

\begin{tabular}{|c|c|c|}
\hline Element/factor & genitive & nominative \\
\hline \multirow[t]{2}{*}{ locus } & individuated, specific & geographical concept or type \\
\hline & existential (genitive only) & individuated, specific \\
\hline \multirow[t]{2}{*}{ absentee } & non-referential (genitive only) & \multirow[t]{2}{*}{ individuated } \\
\hline & individuated & \\
\hline \multirow[t]{2}{*}{$\begin{array}{l}\text { expression } \\
\text { timeframe }\end{array}$} & \multirow{2}{*}{$\begin{array}{l}\text { stated explicitly in clause or ellipted; } \\
\text { often punctual; always basis for } \\
\text { coordination }\end{array}$} & $\begin{array}{l}\text { often duration; stated } \\
\text { explicitly in clause }\end{array}$ \\
\hline & & $\begin{array}{l}\text { "never" (kind of duration), } \\
\text { can be ellipted }\end{array}$ \\
\hline $\begin{array}{l}\text { coordination with } \\
\text { element outside the } \\
\text { clause }\end{array}$ & $\begin{array}{l}\text { obligatory, with an observer, } \\
\text { situation or event }\end{array}$ & $\begin{array}{l}\text { possible, but not relevant to } \\
\text { text organization }\end{array}$ \\
\hline $\begin{array}{l}\text { pattern } \\
\text { influences }\end{array}$ & present; multidirectional & $\begin{array}{l}\text { usually not relevant, possibly } \\
\text { unidirectional }\end{array}$ \\
\hline $\begin{array}{l}\text { reference: } \\
\text { continuity of } \\
\text { cohesive line }\end{array}$ & $\begin{array}{l}\text { individual removed from center, in } \\
\text { comparison to other, (centered) } \\
\text { entity; can resume narrative center }\end{array}$ & $\begin{array}{l}\text { centered individual in a } \\
\text { textual interval }\end{array}$ \\
\hline
\end{tabular}




\begin{tabular}{|l|l|l|}
\hline & in following clauses. & \\
\hline point of view & $\begin{array}{l}\text { often multiple POV: absentee, } \\
\text { observer, narrator, shifting POV }\end{array}$ & absentee POV \\
\hline emotional attitude & $\begin{array}{l}\text { often emotionally colored, relative } \\
\text { to the coordinated event/situation; if } \\
\text { coordinated with central individual, } \\
\text { he/she often expresses opinion or } \\
\text { emotion about absentee }\end{array}$ & \\
\hline
\end{tabular}




\begin{tabular}{|c|c|c|}
\hline $\begin{array}{l}\text { main semantic } \\
\text { templates }\end{array}$ & $\begin{array}{l}\text { Coordinated with an event: } \\
\text { - } \text { explaining the state of affairs } \\
\text { - making excuses for the state } \\
\text { of affairs } \\
\text { - lack of information : often } \\
\text { connected to making excuses } \\
\text { - alibi } \\
\text { expressing regret } \\
\text { absence at moment of death } \\
\text { - often connected to } \\
\text { expressing regret \& other } \\
\text { gen. templates }\end{array}$ & $\begin{array}{l}\text { Absence as individual } \\
\text { property : } \\
\text { - Stand-alone statement } \\
\text { of absence for a } \\
\text { period of time } \\
\text { - Never visited a locus } \\
\text { - Lack of information }\end{array}$ \\
\hline
\end{tabular}




$\left|\begin{array}{|l|}\text { Coordinated with another } \\ \text { individual: } \\ \text { Coordinated individual is } \\ \text { using the absence to engage } \\ \text { in unexpected activity } \\ \text { Coordinated individual is } \\ \text { expressing emotion about } \\ \text { absence/absentee }\end{array}\right|$

\subsection{Data Collection}

I have gathered my corpus in December 2003-February 2004, using Google searches. A wide variety of genres of texts were examined: original twentieth-century literature, literature in translation, fan fiction, newspaper articles, interview transcripts, on-line forums and diaries. The examples gathered encompass a wide variety of styles and registers, from the formal newspaper reporting to the colloquial, casual forum and on-line diary writing.

Originally I examined the examples gathered from the Internet in comparison to literary examples, which I have collected from the works of original $20^{\text {th }}$ century fiction. Electronic versions of these works are available online at Moshkov's library 
(http://lib.ru). The literary corpus might be expected to exhibit a certain, although not complete, uniformity of style and register, in contrast to the heterogeneous Internet corpus. However, I have not observed a significant difference in usage of genitive/nominative negated constructions between these corpora. The sources for the literary examples are cited.

\subsection{Structure of the article}

The article is divided into two main sections. The first section deals with the factors and combinations that result in a choice of genitive case for the absence clause. The genitive is rich in factors and possibilities that prompt case choice, and genitive absence clauses are statistically more frequent. The discussion of the genitive strategy is therefore quite large and complex. Discussion of genitive choice is divided by locus type - individuated and existential; by absentee individuation - non-individuated and individuated. I further examine textual considerations such as coordination with another event or individual and pattern of influences between the absentee and the coordinated event or individual. Finally, I examine semantic templates common to those configurations.

The second section deals with the choice of nominative for the referential subject. It is simpler in its structure, as this strategy exhibits a smaller variety of structural and semantic possibilities. In this section I discuss locus types (individuated and generic), attributive and cohesive motivations that prompt the choice of nominative, the temporal 
specification of duration which is prominent in nominative absence clauses, and common semantic templates.

\section{Genitive Absence Clauses}

In absence clauses with genitive marking of the referential subject (here genitive absence clauses or GACs), two types of loci occur: a specific, individuated locus (such as дома, в Москве), or an existential locus (в мире, на свете, на земле). The ABSENTEE, i.e. the animated referential subject, can be either individuated (мамы не было) or non-individuated (пассажиров не было). While individuated absentees can appear in genitive and nominative absence clauses, the non-individuated absentees appear only in GACs. The timeframe is often specific to the absentee and locus discussed: for example, an absence construction with an individuated absentee in an individuated locus always involves a coordination, either with an event taking place in the same locus at the same time, or with a situation where another individual is present in the locus.

\subsection{Individuated locus}

\subsubsection{Non-individuated absentee(s)}

In a narrative situation that involves a combination of abstract absentees and individuated locus, the locus is emphasized - it becomes a center of narration in the absence clause or 
the narrative interval. Thus, example (1) involves a paragraph-long description of a car, an individuated locus from which non-individuated passengers are absent:

$$
\begin{aligned}
& \text { (1) } \text { в воротам сада, непрерывно ахая и стреляя, } \\
& \text { подъехал зеленый автомобиль, на дверце которого } \\
& \text { была выведена белая дугообразная надпись: "Эх, } \\
& \text { прокачу!" Ниже помещались условия прогулок на } \\
& \text { веселой машине. В час-три рубля. За конец-по } \\
& \text { соплашению. Пассажиров в машине не было. (И. Ильф и } \\
& \text { E. Петров. Двенадцать стульев) }
\end{aligned}
$$

From the narrative perspective, the car is the focus of narration. The vehicle is elevated to the status of an individual: it drives ахая 'sighing', and the first person of $\ni x$, прокачу can be attributed to the car. The absentees are hypothetical, faceless passengers. Thus, the absence of passengers is a statement about a car.

A similar pattern can be observed in (2) and (3). In (2), a collision of a bus and a tram is discussed. Both vehicles are foregrounded; the lack of passengers in the bus is a property of the locus rather than a statement about the individuals:

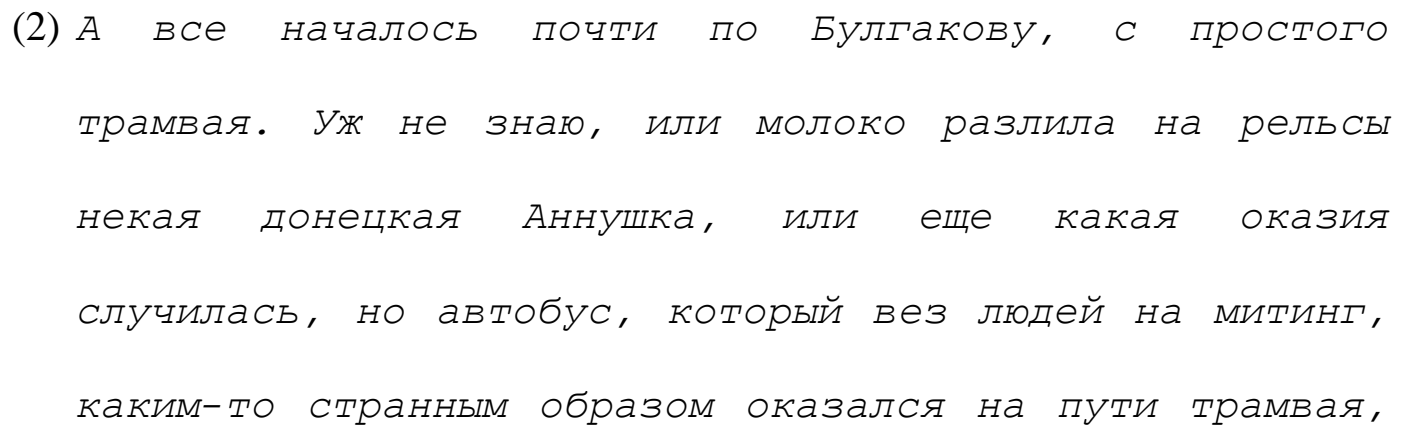




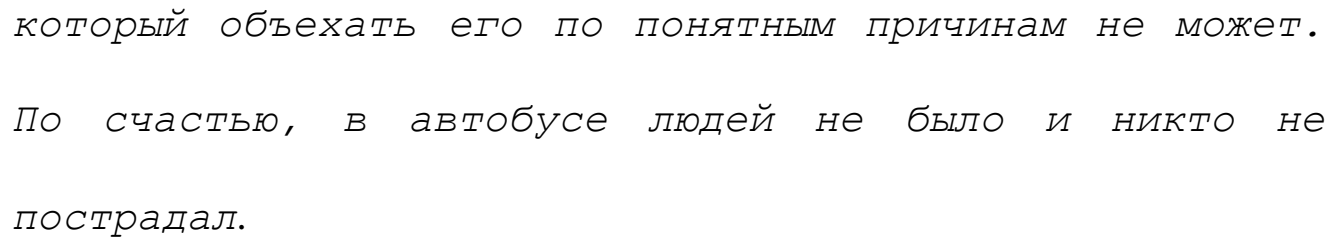

In (3), we find a description of a rabbit exhibition, which is both a location and an event. There are no visitors there, only pet owners and judges. The statements about the presence or absence of individuals are a part of the description of the exhibition:
(3) Первая часть выставки проводилась в субботу 24 мая, посетителей не было, были только эксперты и владельцы.

To summarize, this combination involves abstract and hypothetical persons that are absent from a highly individuated and foregrounded locus; the possibility of individuals' location in this locus is negated. The hypothetical possibility of containing individuals is a feature of the locus itself: it is a feature of the car that it can have passengers, a feature of an exhibition that it can have visitors, etc. The fact that it does not contain any individuals is an accidental property of the locus in this particular situation.

The locus is the center of narration at the moment when the absence of individuals is asserted, but the individuated locus does not tend to occupy the center of narration for a prolonged textual interval: the scope of this centering in the text is local and limited. The focus usually shifts back to persons, thus for example, (2) continues with

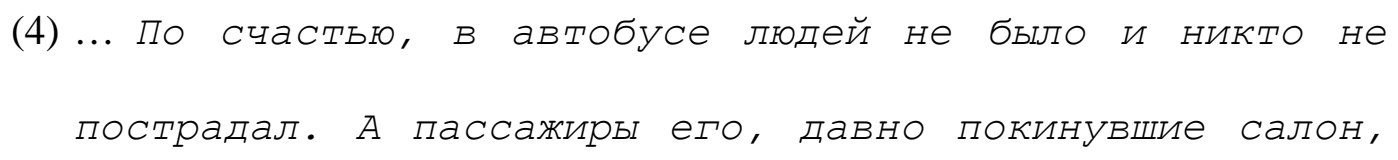




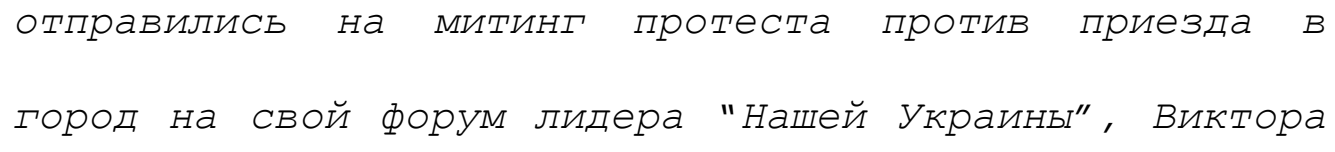

Ющенко.

Here the narration shifts to the formerly hypothetical passengers as they relate to another individual (Viktor Iushchenko), who is the real focus of this narrative.

\subsubsection{Individuated absentee(s)}

A statement of absence that involves an individuated locus and absentee presupposes coordination with another event or situation; the expression of absence is relevant to the general discourse because it is connected to other situations. There is often a causal connection between the absence of the individual from the locus and another situation associated with this locus. In example (5), the speaker is promoted (coordinated event) without being asked first, as she is absent from Moscow, and thus from the workplace, at the time (coordinated absence):

(5) Меня выбрали на эту должность (coordinated event), не спросив моего согласия. Меня в это время (temp) вообще не было в Москве(locus).

The expression of a timeframe (such as $в \quad э т о$ время above) often serves as a basis for coordination of the two situations. In some instances (like example (5)), the coordinated situation is a holistic event, while in others the coordinated situation concentrates on an individual, present in the locus: 
(6) Максим долго бегал в поисках анестезиолога (situation of presence), вначале её не было_(situation of absence), потом она курила ...

\subsubsection{Coordination with an event}

Two situations can be syntactically coordinated on a sentence level, or in the larger narrative interval. Within one sentence, this is often achieved by subordination or by including the event of absence in parentheses. In addition, the coordinated situation isn't always overtly expressed in the clauses immediately adjacent to the GAC - it can be established throughout the narrative, invoked through common knowledge of the interlocutors, etc. In example (7), absence is added in parentheses to the coordinated situation where the name of the father is absent from the birth certificate (this is caused by his absence when the registration took place):

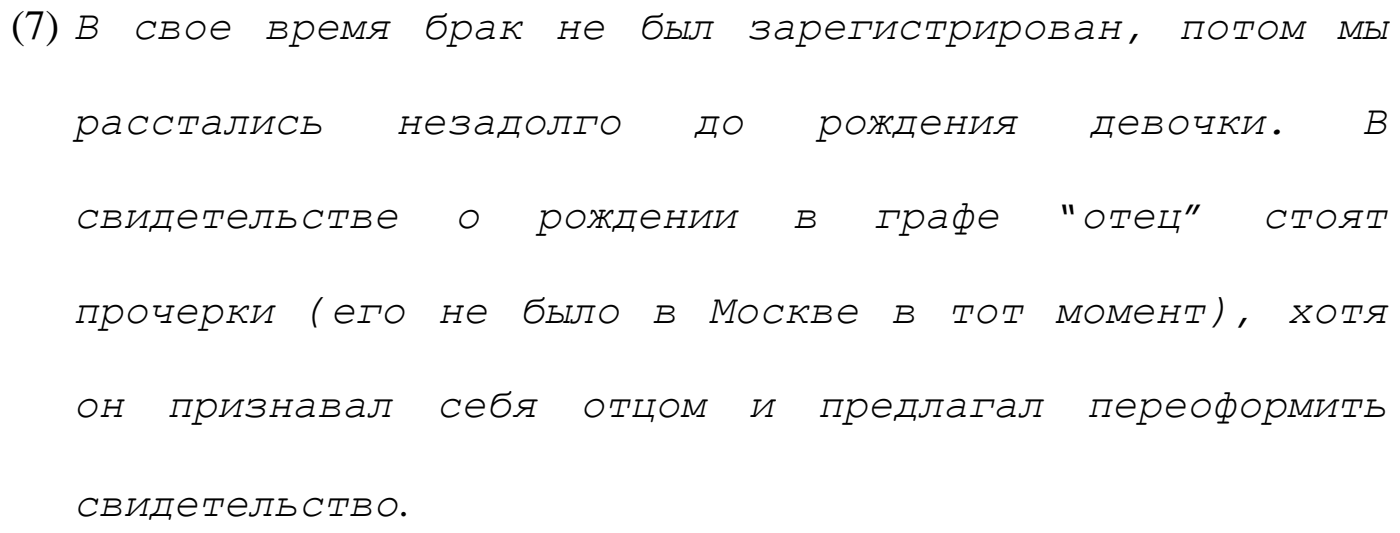

In (8), the individual's absence is expressed in the main clause, and the coordinated event is found in the subordinate clause. In this ironic narration, the 
individual does not know the multiplication table. He is absent from school on the day of the coordinated event (learning the multiplication table):

(8) В Пту меня почему-то не приняли. Сказали, что надо, как минимум, хотя бы таблицу умножения знать. Не стали разбираться, что когда эту чертову таблицу проходили, меня не было в школе по уважительной причине.

Syntactic coordination throughout a narrative interval often occurs when an extended period of time is involved. While the absentee is away, a set of conditions develops in a locus. For example, in (9), the common locus is an internet site. The visitor knows from prior communication that updates are expected to appear. The web administrator responsible for the updates was absent from Moscow, thus by metonymy from the Internet as well (presumably he has internet access only in Moscow). During his absence, something happened to the updates:

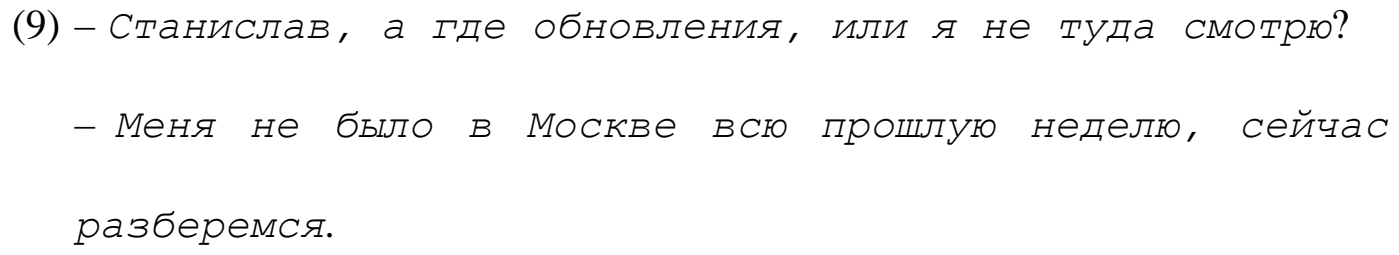

2.1.2.1.1 Textual considerations: pattern of influences between the two coordinated situations 
From the textual perspective, it may seem that the coordinated event is the foregrounded topic of discussion, while the situation of absence is backgrounded. For example, in (5), the main topic is promotion, in (7), the registration of birth is central to the discussion, in (8) it is the repercussions of not learning the multiplication table, etc. However, such a binary approach to textual ranking does not do justice to the complex pattern of mutual influences between the two coordinated situations. For example, in (7), the father's name is not registered in his daughter's birth certificate as a result of absence from the registration. This impacts the father, who later suggests that the certificate should be changed. In (8), the situation of learning the multiplication table in class is coordinated with the situation of absence; the coordination results in the absentee's lack of knowledge. This lack of knowledge, in turn, influences the absentee, who cannot be accepted to a practical studies school (ПTУ).

Sometimes the absentee's reaction to event + absence coordination is emotional. In example (10) below, the absentee expresses regret that he couldn't take direct action as one of the protectors of the White House. His absence prevented the individual from influencing the coordinated situation: if he had been in Moscow at the time, he could have participated in protecting the White House and thus could have influenced the events of 1993:

$$
\begin{aligned}
& \text { Август того года в сравнении с октябрем } 1993 \text { года } \\
& \text { можно считать не столь значительным событием. Жалею, }
\end{aligned}
$$




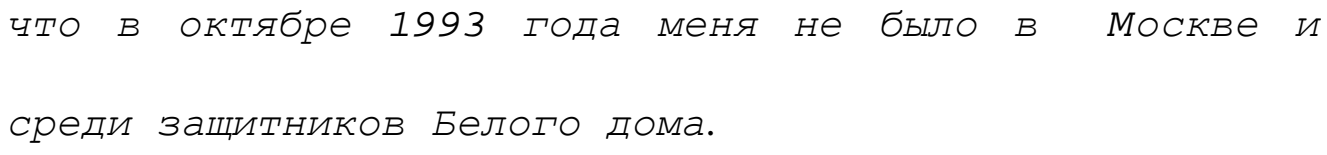

Similarly in example (11), the absentee (Lilya Brik) thinks she could have influenced the coordinated event (Vladimir Mayakovsky's suicide), had she been present:

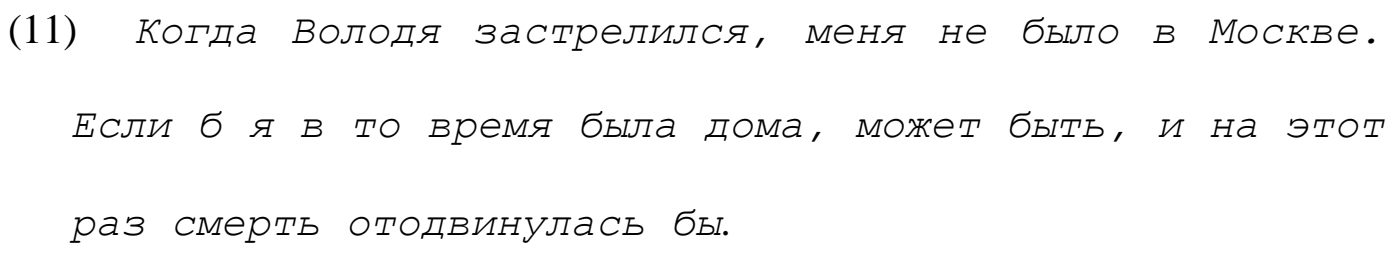

From the examples discussed above it should be clear that the pattern of influences between absence and the coordinated event is likely to be multidirectional. Two possibilities can be distinguished.

The absence influences the event: for example, absence of the father influences the process of birth certification, etc. In many narrative situations, the influence on the coordinated event is potential rather than real, so in (11), the absentee builds a conditional mental space in which she could have prevented Mayakovsky's suicide. As we have seen, the situation of absence can affect the whole event; a more complicated pattern of influences is possible, where the nexus of absence + coordinated event influences another person(s) associated with the event: for example, in (9) a site visitor is inconvenienced by lack of updates that are related to the webmaster's absence; in (12) below, the recipient of the late birthday card is affected - the absentee could not send the card on time due to his absence: 


Вадим! От всей души поздравляю вас с Днём
Рождения! (хоть и $е$ опозданием - меня не было в
Москве).

The event or the fact of absence from the event affects the absentee: for example, the absentee is inconvenienced by court summons, which happens at the moment of his absence, as in (13) below:

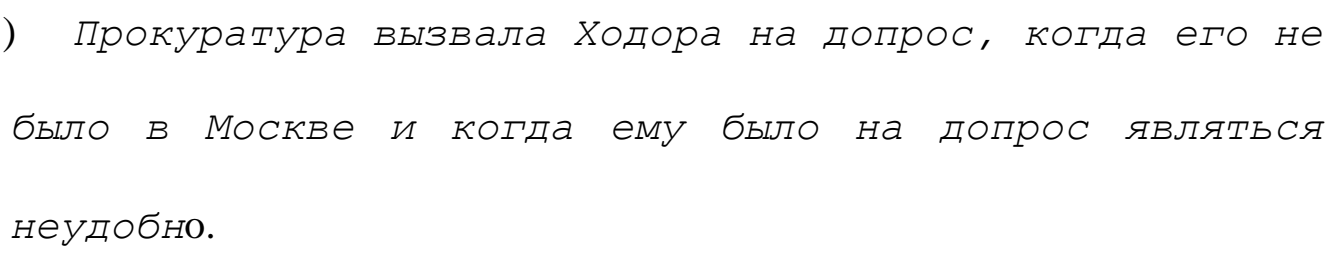
неудобно.

The influence on the absentee might be purely emotional, this can happen if an event in the past (death, demonstration, concert) can no longer be influenced by the absentee, except in an imaginary mental space; or, if the coordinated event is still in power, the absentee may choose to affect it now (absence from birthday might result in a belated greeting; absence from on-line when updates disappeared might result in restoration of updates).

By either influencing the event or experiencing emotions about it, the individual can re-center the narrative on him- or herself; the textual importance of coordinated event is lessened. Such recentering often happens in an adjacent clause, where the individual (the former absentee) is referred to by nominative subject or by a verb with an ellipted nominative subject. For the nominative subject see (11), если б Я $в$ то время 
была дома; for the verb with ellipted subject, see for example, (10) жалею. Such recentering often happens for first-person genitive subjects, for example in (14) below:

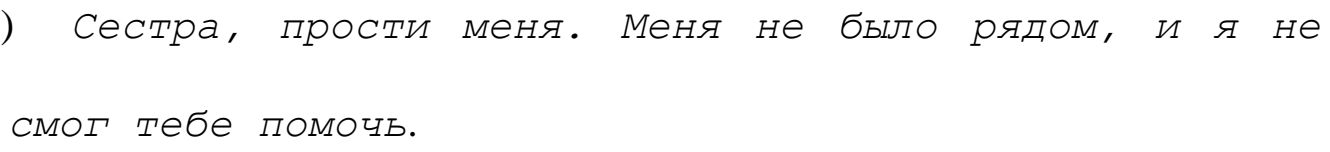

\subsection{Common semantic templates}

The absence + coordinated event scenario lends itself to an inventory of common semantic templates. They generally deal with reacting to an event which happened during the absence - thus, for example, it can involve explaining the state of affairs by absence, making excuses for the state of affairs, producing alibis, etc.

One common semantic template is making excuses: the individual was absent for a period of time, and for this reason he/she was unable to react to the coordinated situation in the expected fashion. In (15), the absentee apologizes that she was unable to answer a letter in a timely fashion:

$$
\text { Извини, что отвечаю тебе с опозданием: ваши письма }
$$

пришли, когда меня не было в Москве.

This semantic template usually involves a belated action that is influencing the coordinated event after the absence is over (as discussed in 1.2.1.1): here the former absentee reacts by apologizing and answering the letter.

The next semantic template involves the absentee expressing his or her lack of knowledge or information regarding the situation that developed during the period of 
absence. This lack of knowledge often implies that the absentee was not able to undertake the necessary actions connected with the situation. In (16), a woman couldn't visit a sick person earlier: because she was out of town, she was not notified. Now that she received the information, she was able to act upon it:

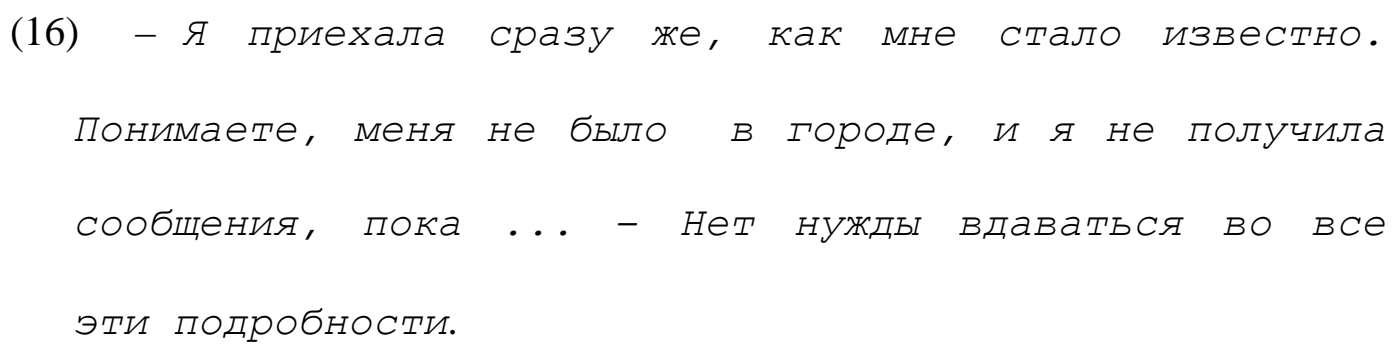
This template also can involve a belated action that can influence the coordinated event after the absence is over.

Another template is the alibi: the absentee explains why he could not be involved in a certain event. So in example (17), Kosygin attempts to prove his innocence by saying that he was not present in Kiev at the day the murder was committed:

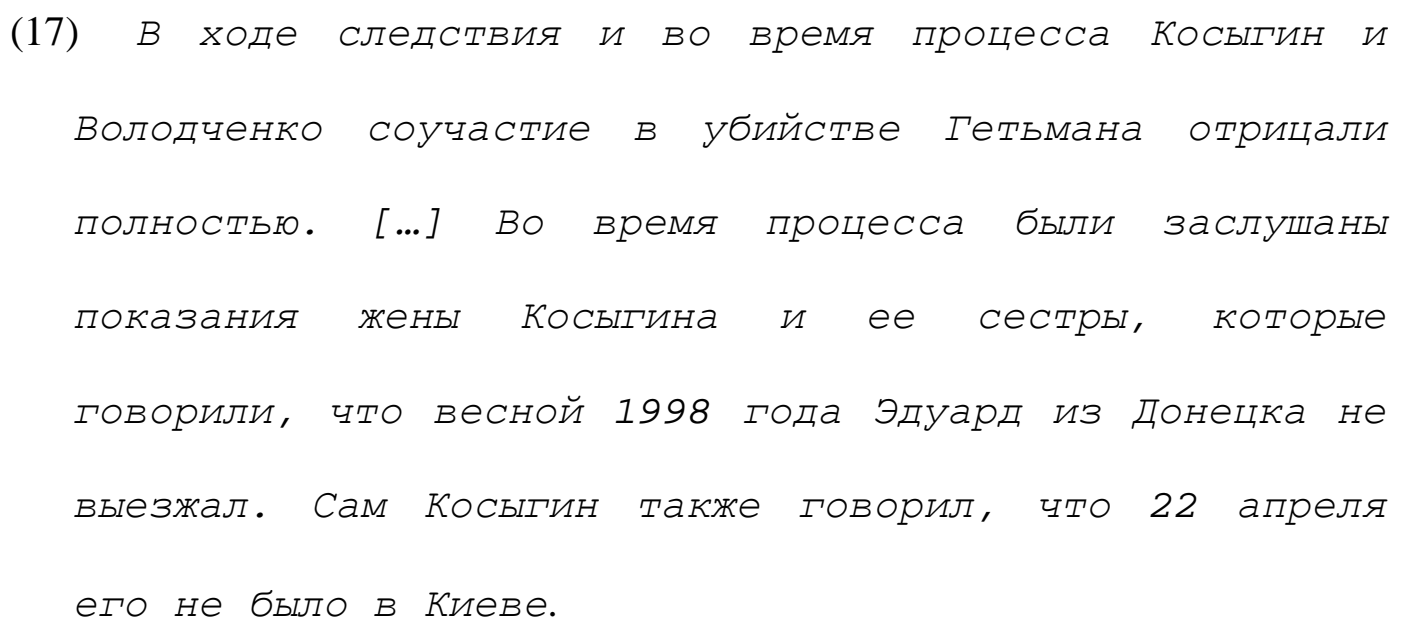


Emotional reaction to absence and its implications is also common. Regret for not being able to attend a coordinated event is expressed, for example, in (18), where absence from the city precluded a fan from attending a concert:

$$
\text { Очень сожалею, что во время вашего визита, меня не }
$$
было в городе и не смот попасть на ваш концерт в Рио.

Emotional reaction is often expressed in connection with an event of death. Surprisingly enough, the combination of GAC + event of death is rather frequent (see also ex. (11)):

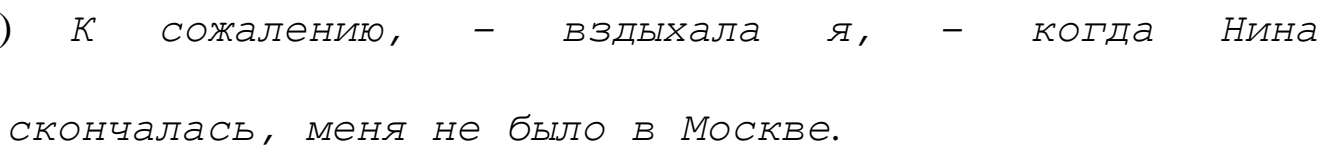

\subsubsection{Coordination with an individual}

In the absence / coordinated event scenario, both the individual and the event can be of equal textual importance: they are coordinated in a setup of possible mutual influences. While the absentee often appears backgrounded in relation to the coordinated event, the absentee tends to reclaim central position in the following clauses: he or she often appears again as subject with nominative reference. This is especially true if the individual is in $1^{\text {st }}$ person, i.e. if the absentee is explicitly marked as the perceiving and experiencing entity of the narrative interval.

A slightly different situation occurs when the coordinated situation is concerned with the presence of individuated person, rather than with an event. This coordinated situation of presence is then parallel to the situation of absence: a concrete individual, 
additional to the absentee, is involved with the common locus. In (20), the coordinated individual - Gogol - is contrasted to the absentee, the princess Volkonskaya:

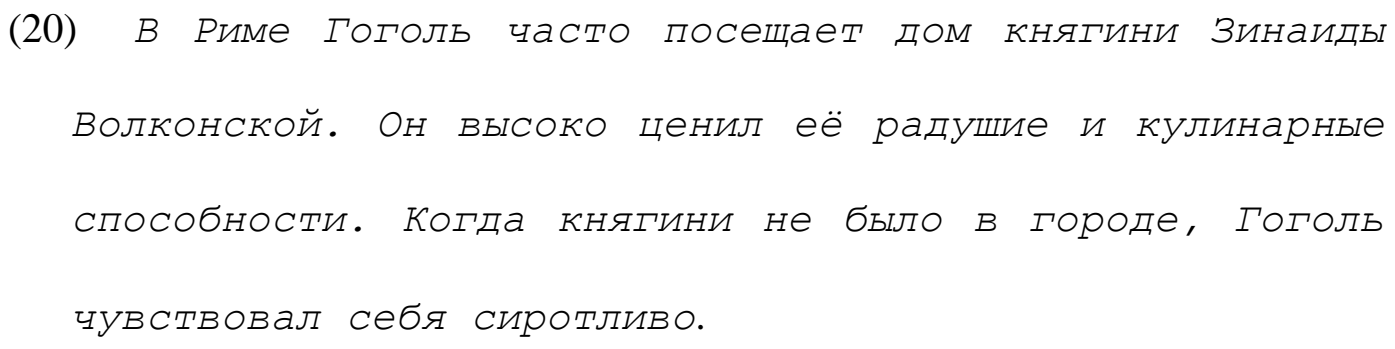

2.1.2.2.1 Textual considerations: interaction between the two coordinated individuals The coordinated individual is often the focus of narration, as in (20), found in a text written about Gogol and his experiences abroad. If the perceiving entity other than the absentee is the focus of the narration, the references to the absentee tend to appear, often consistently throughout a narrative interval, in an oblique case - note the genitives of КняГини and её in (20).

Similarly in (21), the nominative-marked central individual, Nikita, is the main perceiver of the narrative. He does not find Liuba at home. Throughout this interval, Nikita has the central role of subject with nominative reference, while the absentee, Liuba, is referenced with the genitive and then the accusative.

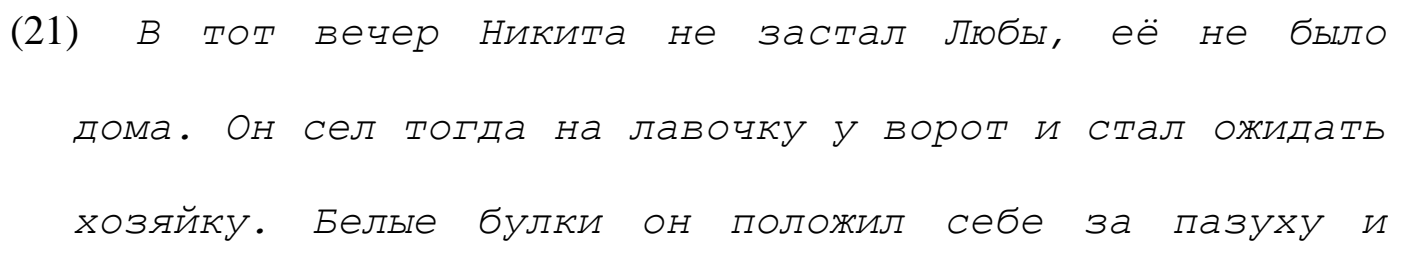


согревал их там, чтоб они не остыли до прихода Любы

(Андрей Платонов. Река Потудань)

We have examined the scenario where the coordinated individual is always central (with nominative reference), while the absentee is always backgrounded (with genitive reference in the negated clauses). Another possibility is that both the absentee and the coordinated individual can potentially claim the center of the narrative, i.e. a shift of centers can occur. So in (22), the narrative interval has two individuals who take turns as perceiving entities. The first centralized individual shares a locus with a person named Burbage. The first individual is marked by nominative through most of the narrative interval. When the focal individual's presence in the locus is contrasted to Burbage's absence, the absentee is marked genitive while the centralized individual is marked nominative. After the discussion of presence/absence and the corresponding nom/gen marking, the focus of the narrative shifts to Burbage, who is referenced by the nominative pronoun $\mathrm{OH}$ :

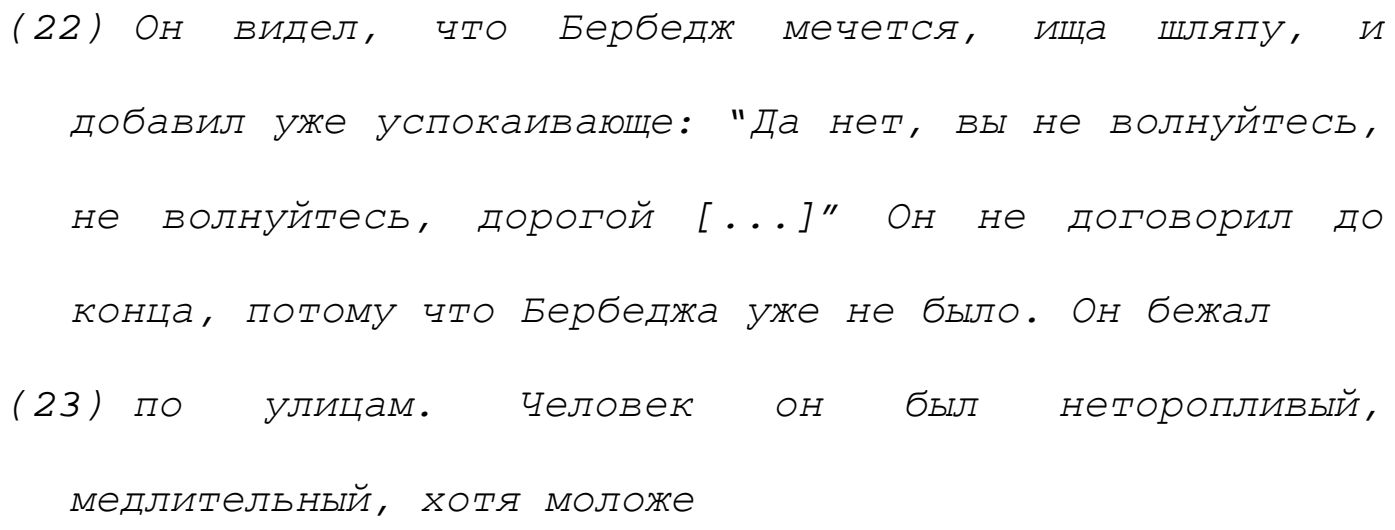




\section{(24) Шекспира, но уже тоже в летах и всегда помнил об этом. Но сейчас он

In a situation where two individuals can occupy the narrative center, the perceiver - central individual - is often in first-person, while the absentee appears in third-person; however, the narrative construction is not limited by this choice of reference; for example, in (23), the first-person speaker shifts the role of the perceiver, and the narrative center, from himself to his interlocutor. The second-person reference is marked nominative, while the first-person appears in the oblique genitive:

Вы не слышали моего голоса, потому что меня там не было.

My description of the coordinated individual scenario elaborates on Paducheva's notion of observer (Падучева 1992, 1997). In my opinion, Paducheva's observer often proves elusive, since she does not distinguish between coordinated event and coordinated individual scenarios: in the coordinated individual scenario, a perceiving entity in a situation of presence is contrasted to another individual in a situation of absence; in the coordinated event scenario, a focal event is in contrast to backgrounded absence. The event and the absence can exert influence on one another; the implications of absence can also influence another person: for example, in (9) where the webmaster's absence results in disappearance of updates - and this in turn has impact on the site visitor. 
This potential additional individual is also classified as observer by Paducheva. However, in my opinion, the absence/event coordination is focal in this scenario; as we have seen, this coordination implies a pattern of influences and usually appears in a number of semantic templates. It is not so in the coordinated individual scenario. In my classification, the genitive assignment is only prompted by another individual when this individual is in a situation of presence, focal at the moment of the referential subject's absence, and is syntactically contrasted to the absentee.

Example (24) illustrates this. Here we have two interlocutors marked with the $1^{\text {st }}$ person reference: the female detective investigating a murder, and a friend of the victim:

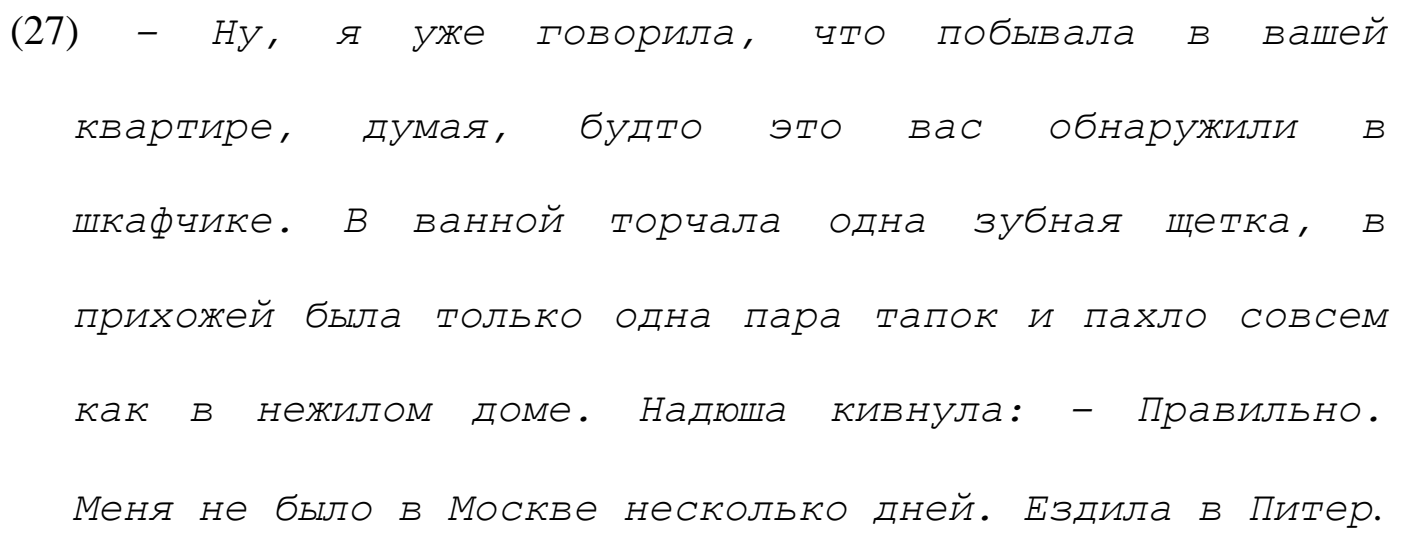

The women are discussing a situation in the locus - the state of disarray of the apartment. What the detective "observes" is not the absence of Nadiusha from the apartment, but the state of the apartment (event/situation). Thus the centralized situation has implications for both absentee and second individual. Nadiusha is backgrounded compared to the event; she explains the unexpected state of affairs by her absence. Note that Nadiusha is then recentered with the ellipted nominative of ездила в Питер (c.f. 1.2.1.1). 


\subsection{Semantic templates of the coordinated individual scenario}

The most common semantic template with the coordinated individual involves a situation where that central, coordinated individual is using the absentee's departure to do something independently - this often involves unexpected or even forbidden actions. For example, in (25), the daughter is using her mother's absence to try cooking on her own, nearly burning the kitchen in the process:

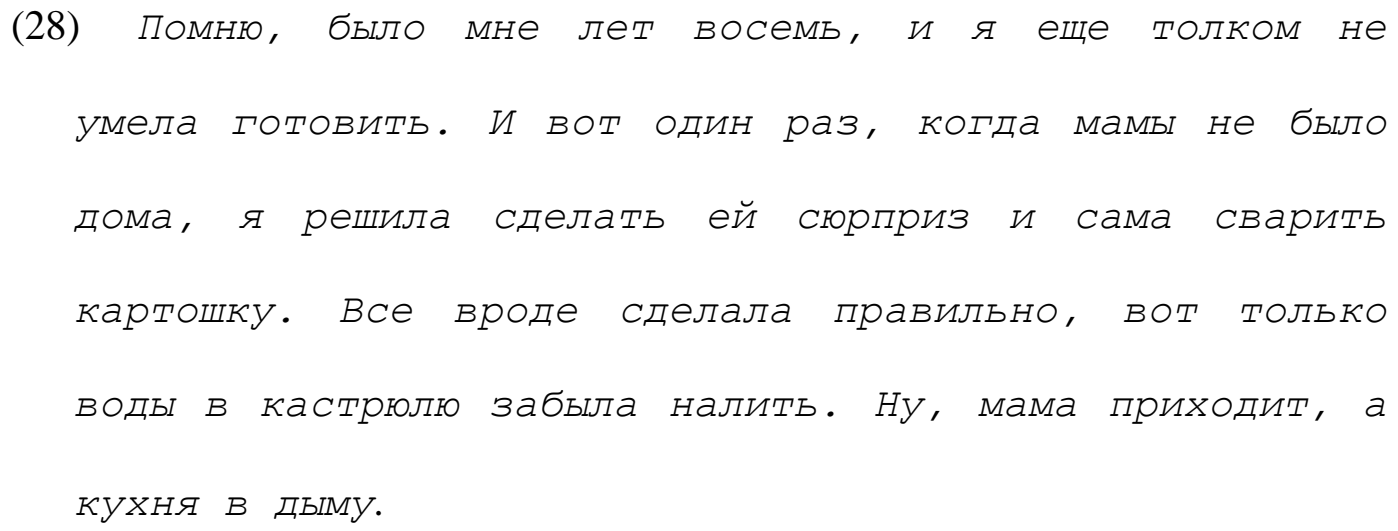

In another common template, the centered individual expresses regret about the absence of another person. For example, in (26), the sportsman is unhappy that his trainer is absent and thus unable to help him compete:

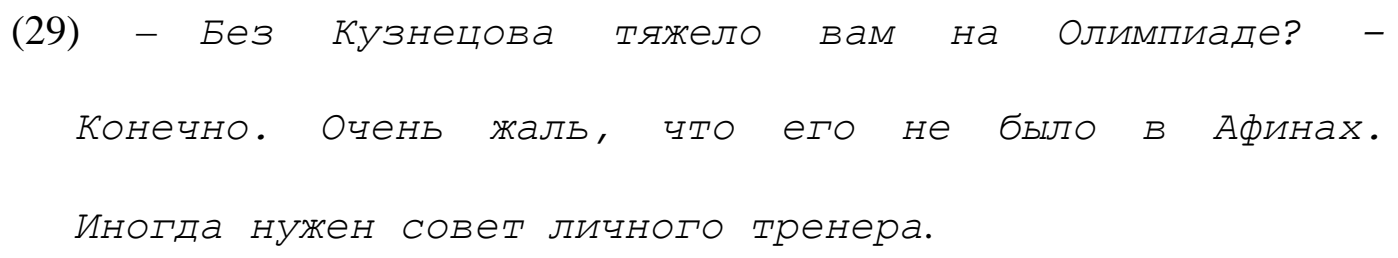


In comparison to the coordinated event scenario, there seem to be less fixed templates involved. In terms of the pattern of influences, the situation is also less complex - usually only the coordinated individual is impacted by the absence.

\subsection{Existential Locus}

The individuated loci discussed in 2.1 can appear both in nominative and in genitive absence clauses. Unlike them, existential containers appear almost exclusively in genitive absence clauses.

By existential containers I mean, first of all, a type of locus that is expected to contain the individual throughout the stages of his or her life: such are the containers в мире, на свете, на земле. A statement which deals with absence of an individual from such a locus usually deals with times when the agent wasn't yet born. So, in the example (27) below, a coordinated set of conditions (building of houses) happens at the time preceding Lenin's birth:

$$
\begin{aligned}
& \text { (30) так дома же и раньше строили, когда Ленина не } \\
& \text { было. (Андрей Платонов, Усомнившийся Макар) }
\end{aligned}
$$

\subsubsection{Coordination with event or individual}

A GAC with an existential container is also routinely coordinated on the timeframe: the period of time when the individual was not yet born is contrasted to the coordinated event 
or individual; the pattern of influences is slightly different from that observed in the GACs with individuated loci.

In a coordination of existential absence with a coordinated event, we are asking the question, "does the non-existence of the absentee have an impact on the main coordinated event?" This happens in (27), where the coordination is with an event/situation - construction of houses; the pattern of influences between the coordinated event and the existential absence is examined, and the observation is that the event is not influenced by the individual before or after his birth. However, the possibility of such influence is the point of the clause. One can conceive of an utterance where Lenin's existential absence would have an effect on the coordinated event, for example, there was no electricity before his time, but this changed due to his activity.

Coordination with an individual is also possible. For example, in (28), the coordinated individual, the writer Nick Perumov, is talking about his history as an author::

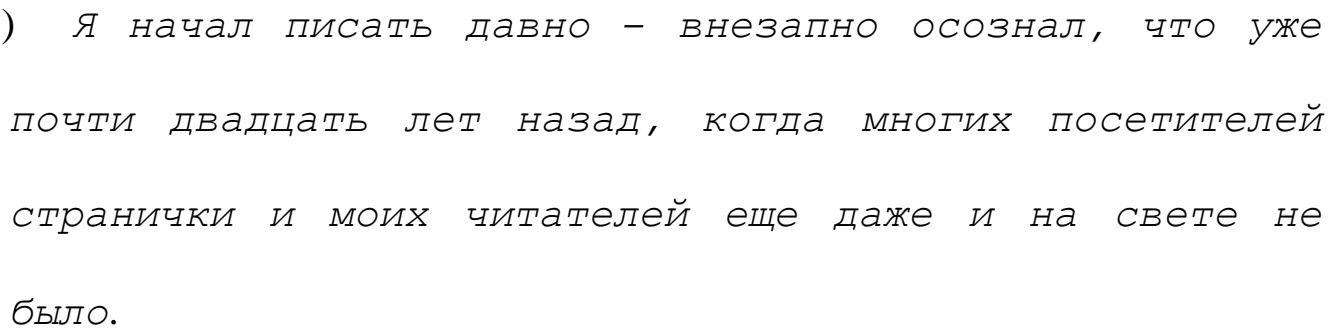

The coordinated individual is explaining that he was engaged in the process of writing before his readers were born. By producing this sentence, he invites his readers to observe the process of writing (to influence and be influenced by it), even though it 
happened before their time. A similar semantic situation often occurs when elder people tell stories of their lives to their children and grandchildren; such narrations are often accompanied by тебя еще на свете не было. This is to imply, "although you have not been present at that time, I invite you to observe/participate in the events through this narration. They are relevant to you as a member of the family".

A subtype of the GAC existential construction declares the individual's nonexistence on the timeframe - for example, to point out that the absentee is a fictional character. In this instance, coordination between this total absence and a series of events or conditions is still possible. For example, in (29), an artist is making a sculpture of Shakespeare:

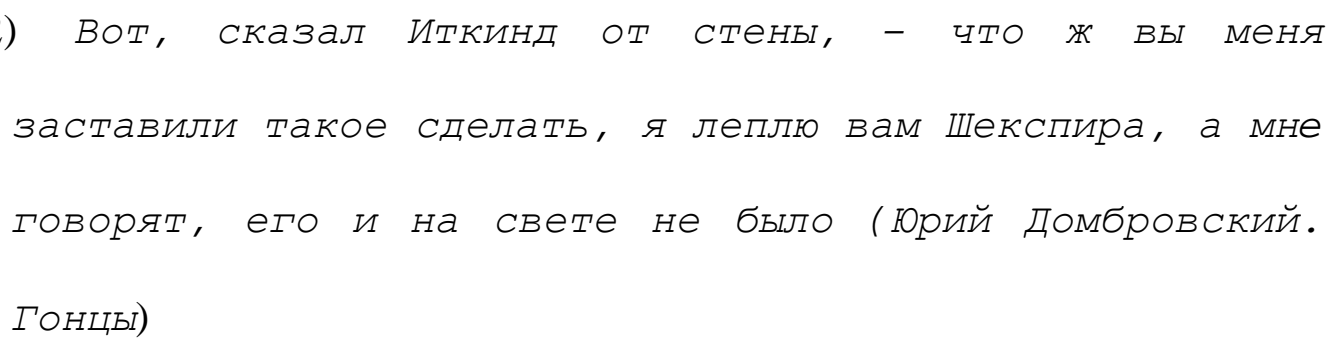

When the sculptor is told that Shakespeare is a fictional character, he complains that his artistic endeavor is hereby rendered useless; i.e. the absence of Shakespeare from existence has a bearing on the coordinated individual.

I have not found a difference sufficient to separate "locative" clauses from "existential" clauses. Like other genitive absence statements, a statement of "negated existence" or absence from an existential container can only appear if it has bearing on another event or situation; coordination of an existentially absent person with another 
individual or event is structurally similar to the regular absentee/event and absentee/individual scenarios. The pattern of influences is slightly different, and a separate set of semantic templates can be expressed in such constructions (see Table 2).

However, "existential" semantic templates such as "including individual into narrative that predated his/her birth" can also appear in a modified form with nonexistential containers - and with non-genitive verbs. For example, an employee might include a colleague in the workplace narrative that predated his/her time in two ways: with не было + genitive (30.a), and with a non-genitive verb не работал/a (30.b):

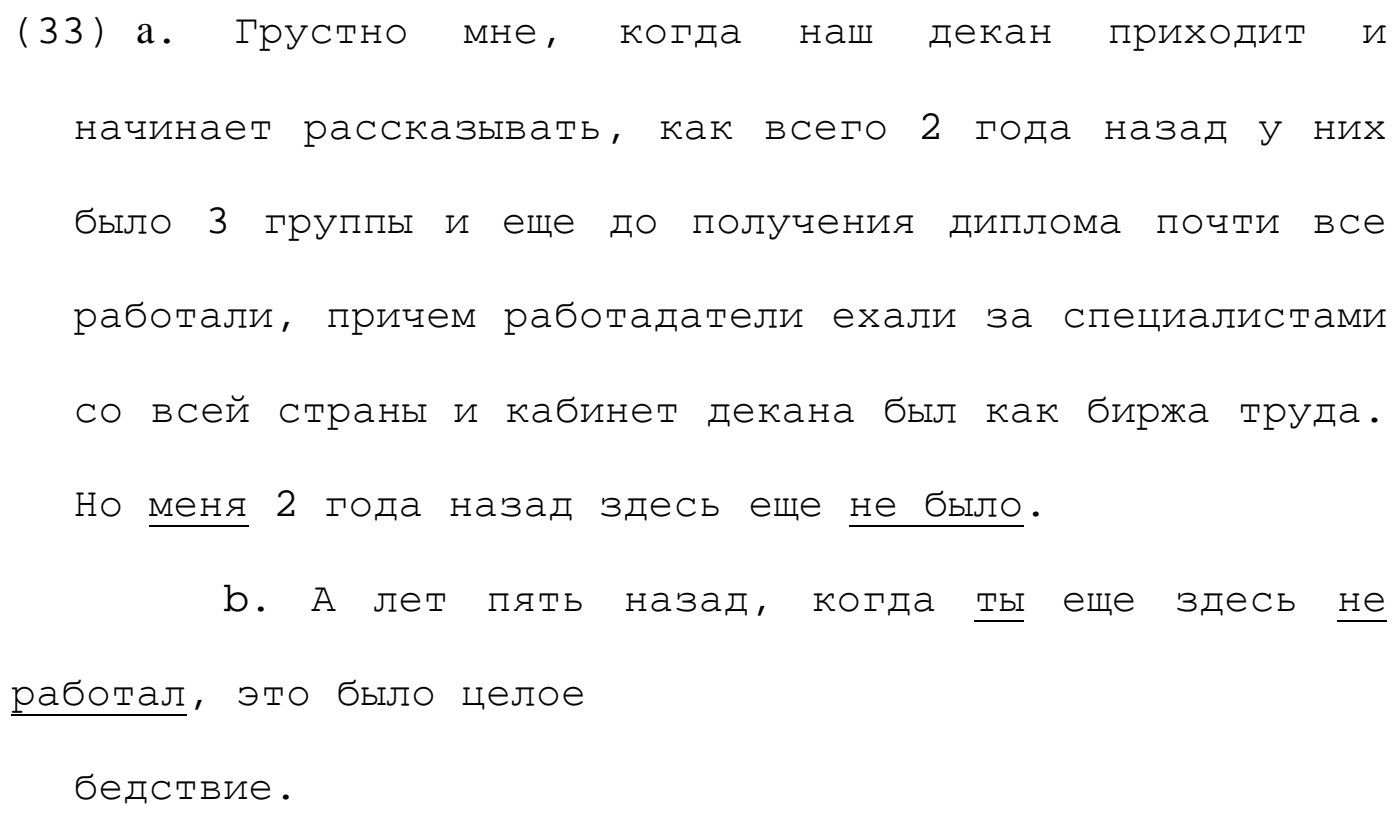

To summarize, non-existence will only be expressed if it has relevance to existence; in this non-existence is only a semantic subtype of genitive absence, which is expressed in connection to other events or situations. 
Table 2

\begin{tabular}{|l|l|}
\hline locus & existential container \\
\hline timeframe & before birth of absentee \\
\cline { 2 - 3 } influences & rare: absentee never existed \\
\hline semantic templates & impact or relevance of absentee or coordinated individual \\
& including individual into narrative that predated his/her \\
& birth \\
\cline { 2 - 2 } & Declaring that non-existence of absentee has impact on \\
& coordinated event or individual \\
\hline
\end{tabular}

\section{Nominative Strategy}

In the discussion of the genitive construction I have examined two scenarios in which the absent concrete individual is marked with the genitive case. Both scenarios involve two components that can occupy the center of narration. In the coordinated event scenario, a textually important event occurs in the locus from which the referential subject is absent at a certain period of time. In the coordinated individual scenario, there is another individual who occupies the locus from which the individual $\mathrm{GEN}_{\mathrm{GN}}$ is absent at a certain period of time. In both scenarios, the individual is decentralized at the moment of 
absence, but maintains the potential of reclaiming the center of the narrative in the following clauses. I have noted that in the narrative interval that includes the GAC, the centered coordinated individual is marked with the nominative case. The absentee is marked with genitive at the moment of absence, when he/she is opposed to the present and central individual marked with nominative. In the nominative strategy, the absentee is marked nominative even at the moment of absence; predictably enough, this happens in a situation where the absentee never loses his/her central position in the narrative.

The assignment of nominative under negation was previously connected to centering or focusing on the absentee, so, for example, Timberlake writes that for the negated nominative subject, "the interest is focused on the individual, who is otherwise known, and on the properties of that individual." (Timberlake 2004, 208).

However, the centering on the individual in the nominative absence clauses (NACs) is of a somewhat different kind than the centering in the GACs. There are two motivations (often combined or inclusive of one another) for centering on the absentee: what I would call attributive motivation, and cohesive motivation.

In the case of attributive motivation, the absence or its components (such as the locus) are perceived as a part of the individual's domain, i.e. they are interpreted as one of the individual's personal attributes or as a part of his/her experience. For example, a locus can be important to the utterance only through its part in the individual experience of absence; "Individual $\mathrm{NOM}_{\mathrm{M}}$ never visited place $\mathrm{Y}$ " is a syntactic/semantic template where 
never visiting a locus is an attribute of the individual. Another venue of expressing individual experience is through temporal specification of absence.

Statements that are motivated by attribution often appear in stand-alone sentences, such as я не был на Днепре or она не была в Москве 90 лет.

The individual can also be central to the narrative in terms of text cohesion. Such centering normally has a wide scope in the narrative, where the individual acts as a nominative subject for more than one clause. The narrative tends to focus on one person, who is often the main character; the narrator uses this character's perspective so that the character acts as perceiver.

The attributive and the cohesive motivations often combine. This happens, for example, in first-person narratives, where the perceiver is the main cohesive focus of the story. Such a perceiving entity tends to express various happenings as a part of his/her domain of individual experience rather than as a pattern of influences that develops between different coordinated situations.

Unlike in genitive absence clauses, only individuated and concrete absentees are allowed in NACs.

\subsubsection{Locus as Generic Concept or Type}

Nominative absence clauses, like GACs, allow individuated loci. In genitive absence clauses, the locus acts as a concrete physical entity; even if it is not experienced as 
physical directly due to absence, the locus is nevertheless physical for the coordinated person or event. In addition, genitive absence clauses allow existential loci such as $B$ мире, на свете, на земле; these loci do not appear in NACs.

Some types of loci, however, appear predominantly in nominative absence clauses. These are non-individuated specifications that can be further assigned into three categories: geographical concepts (в Индии, на Днепре), a locus out of an array of loci (в машине Формула 1), and generic concept loci (на море).

Geographical concepts appear in NACs routinely in the semantic template "the individual has never visited X". The individual knows the name of location X from a map or from some other source; the locus cannot be individuated in the absentee's perception, since the individual is not familiar with it physically. In the following example, the old man has visited a number of places, which are listed - but he had never visited the Dniepr River:

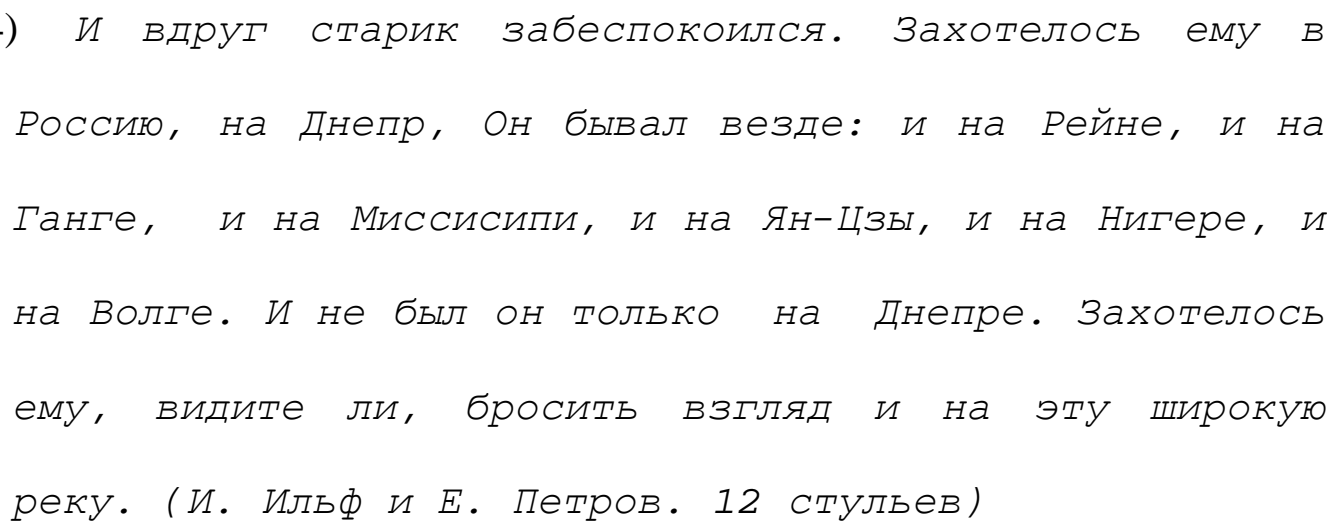


Such a locus, a geographical concept, is a potential property of the individual's domain of experience or knowledge. In (31), the old man is the center of narration, and the fact that he visited some places (which also appear here in non-individuated, listed form), as well as the fact that he hadn't visited others, are a part of the description of this individual's experience regarding travel.

Similarly in (32), the narration centers on the individual and his experience. The individual had never visited TIuZ (Theatre of the Young Spectator):

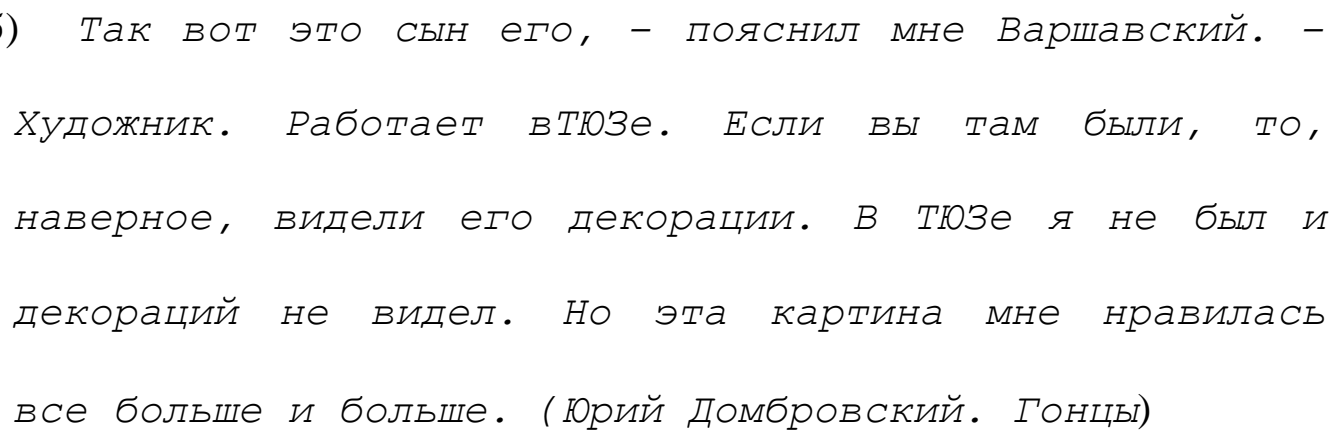

TIuZ, as opposed to the Dniepr in (31), could be interpreted as a concrete, individuated theatre - however, the central individual had not only never been to TIuZ, there is no coordinated event connected to his absence; there is no thwarted expectation of presence and no pattern of influences; the locus TIuZ is an abstract concept in the perception of the individual, and as such it is a property of the individual's perception, not a separate physical entity.

Another type of non-individuated locus is a locus out of an array of subtypes: for example, a car of a certain make, a store out of a chain or stores, etc. This locus type also 
appears predominantly in NACs. The array itself, such as the IKEA chain of stores or the "Formula1" type of car can be known to the individual; however, a single locus out of this array is non-individuated. It is not important for us to know specifics about the locus, other than its belonging to a type. For example in (33), the sportsman participating in the car race is discussing his results:

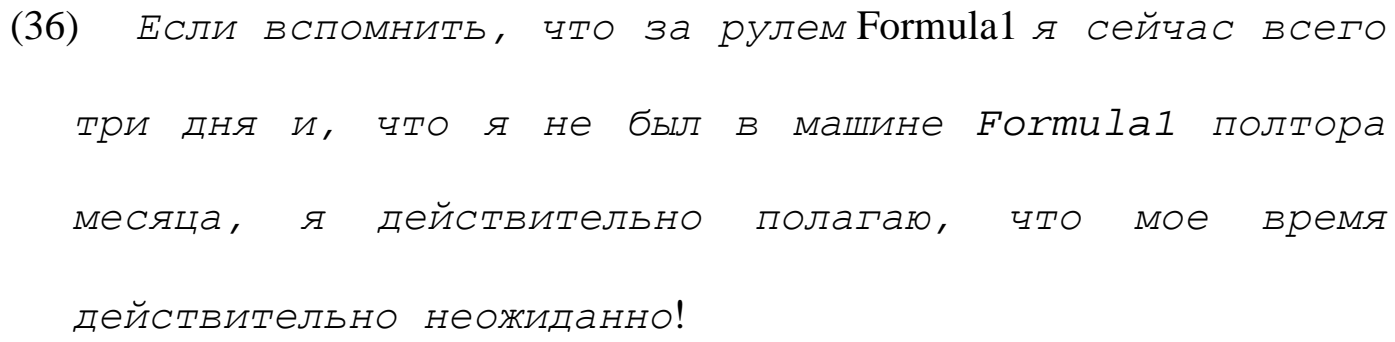

The sportsman's не был relates to the type of car rather than to a specific, individuated car. His absence from Formula1 cars is a part of individual's experience: one of his qualities as a racer is a lack of experience with Formulal cars during a specified temporal interval.

Generic concepts of a location, such as на море, constitute another type that appears predominantly in the NACs. These loci indicate an abstract concept such as "any sea" or "the sea as a type of location" or, by metonymy, "vacation at a seashore"; these loci can never be individuated. The abstract locus or event such as море, отпуск, война are relevant in the scope of the individual's experience; absence from these loci is a property of the individual. Although these concept loci appear predominantly in the NACs, they do not "trigger" the nominative case, but rather they themselves are triggered 
by the structure of the message, its centering on the individual and his/her properties. Loci that appear predominantly in the NACs can appear in GACs if coordination is involved, though such examples are rare. In (33), the child Irishka was absent from the sea (unspecified), when the other children were conveying "scientific experiments":

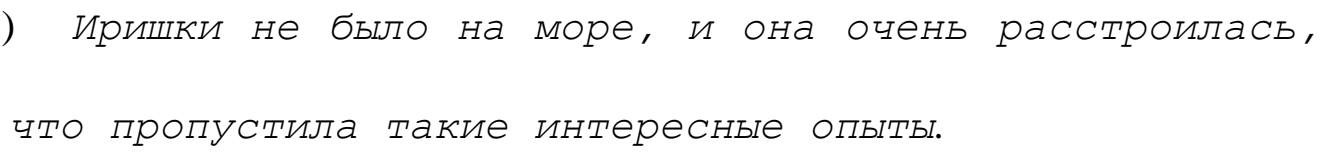

Irishka expresses regret over the fact she was unable to influence the coordinated event, i.e. to participate in experiments, because of her absence. This is a one of the common GAC semantic templates (as discussed in 2.1.2.1.2).

On the other hand, loci that appear almost exclusively in the GACs can appear in a NAC in the appropriate syntactic/semantic template. For example, I found a single example of NAC occurring with $B$ мире. It is extracted from a questionnaire published on-line, in which the author is asking the site readers to choose among a number of readymade sentences which answer the question, "Do I know you from real life, and if so, where could we meet?" The last option reads,

$$
\begin{aligned}
& \text { Я не был в материальном мире вооще (sic), я только в } \\
& \text { Интернете... (ничего, все тАм будем, тАм увидимся). }
\end{aligned}
$$

Here the nominative construction is chosen in opposition to the existential semantics that would be implied if this locus appeared in a GAC. The site author implies that even 
though the visitor is not to be found in the material world, he/she is nevertheless very much in existence; his/her existential container of choice is the Internet.

\subsection{Cohesive motivation}

Unlike the more transparent attributive motivation, the cohesive motivation operates in a wide area of text. The choice of nominative for the subject marking is here relevant to the way the information is organized over a narrative interval. The narration centers on an individual who is the agent of a number of clauses. One of these clauses is the event of absence, where the individual is also marked nominative. There is no tension between two situations as there is in the genitive strategy; another event or person can indeed be coordinated to the absence - but this event or individual will be interpreted from the point of view of the perceiving individual, who never cedes his centralized status.

In (36), the narrative is centered on Oleg, the main character of the story. He is the nominative subject of a chain of clauses that describe his activities on the ship. One of those activities is the absence clause:

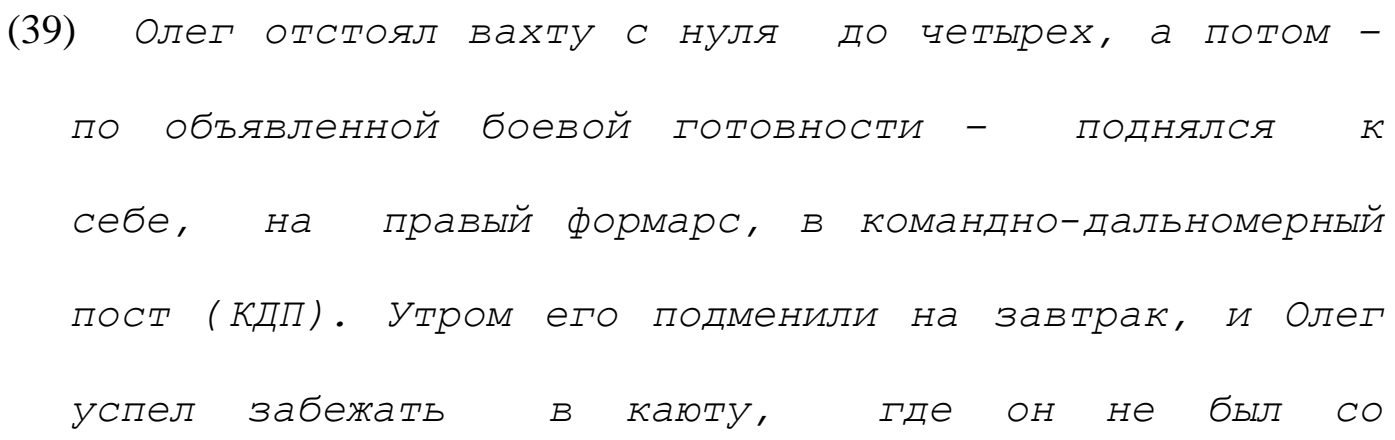




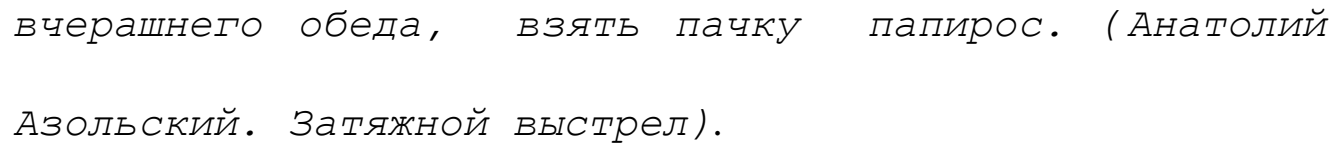

Although other individuals are present, they do not rise to the central position: somebody relieved Oleg from his duty on the post, but the reference in его подменили is impersonal; the usage of an explicit subject maintains a cohesive focusing on Oleg.

The nominative subject syntactically unites a chain of clauses - this unification can often be achieved (or emphasized) through ellipsis of the subject reference in linked clauses:

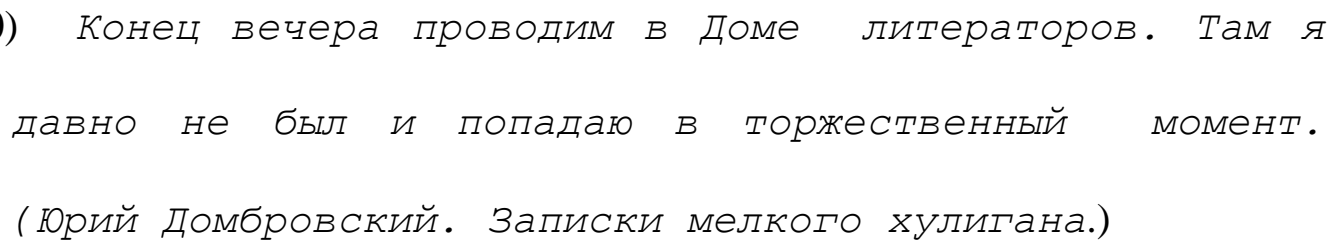

In (38), we find a lengthy monolog of an individual narrating his emotional response to the defense of Ostankino, and his latter reinterpretation of the event. The ellipsis helps establish a centralized cohesive first-person reference throughout the narration, and simultaneously allows us to avoid introduction of other pronominal or explicit nominal subjects. The personal experience and mental processes of the individual are highlighted through the centralized nominative; note the $я$ не $С$ Ними and other nominative subjects in negations, referring to the same person:

$$
\begin{array}{rllll}
\text { я не был в москве, но оба митинга видел } \\
\text { телевизору. Слушал и с волнением повторял за }
\end{array}
$$




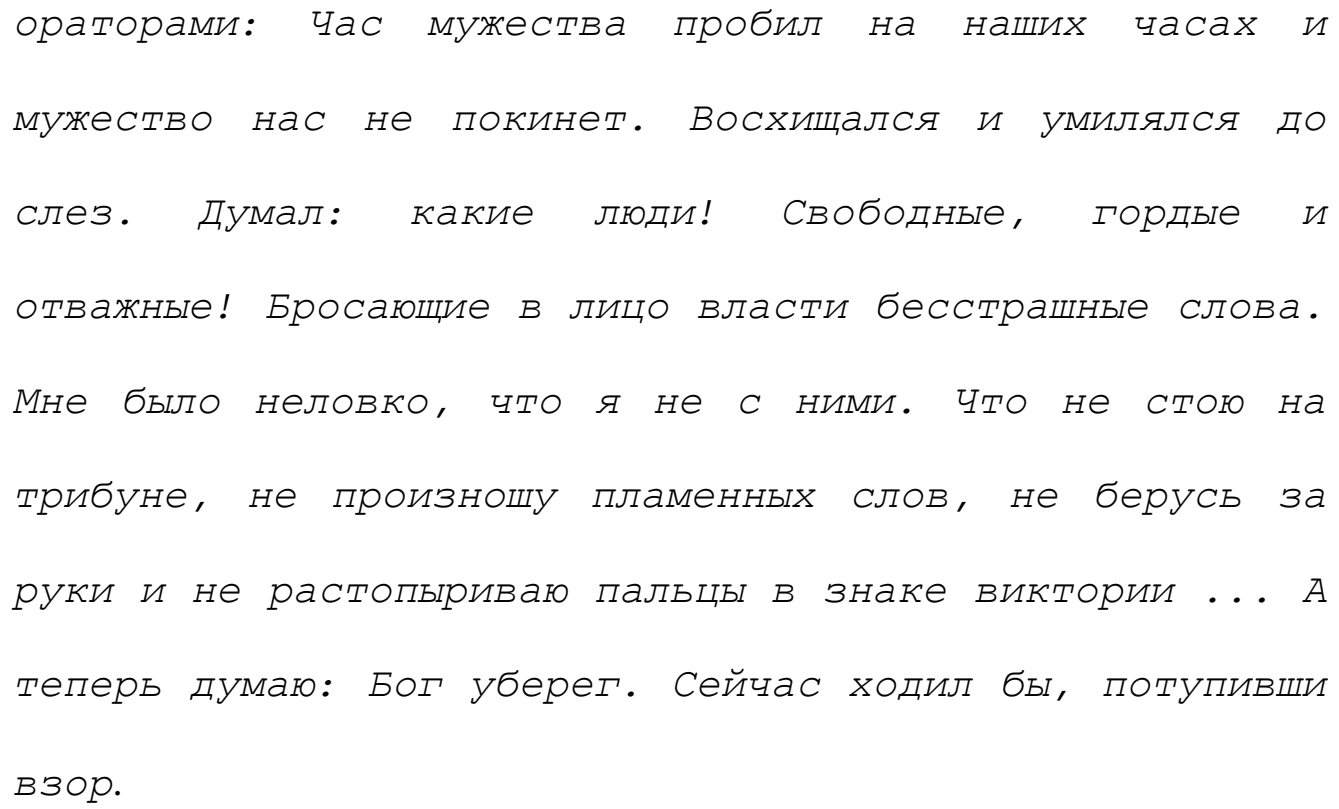

\section{3 Temporal specification}

We have seen that the GACs typically involve coordination of the situation of absence with another situation or event at the same time. Time is important also for NACs, but in a different way. NACs often include a specification of the period of time over which the individual was absent from a locus. In fact, the construction $\operatorname{Subj}_{\mathrm{NOM}} B e_{\mathrm{NEG}} \mathrm{TEMP}_{\mathrm{PERIOD}}$ is basic for NACs, and it often acts as an independent, stand-alone clause.

The TEMP ${ }_{\text {PERIOD }}$ specification can be an accusative time statement (42.a), a "from" statement (42.b), а за statement (39.c), an adverbial specification such as давно or много лет(42.d), or the никогда specification (42.e):

а. Я не была в Москве десять дней. 
b. С 6 июня он не был в Москве, практиковал в других странах.

$$
\text { с. За то долгое время, что я не был в москве, }
$$

Россия изменилась в

лУчшую сторону

d. Я не был в Москве много лет, хотя

и родился в Москве и деды мои

МОСКВИЧИ •

е. Он никогда не был в москве, не мечтал туда

попасть и весьма

отдаленно представлял себе, как она выглядит.

The interval of absence is interpreted through the individual's experience. The absence can be mentioned simply as a feature of the individual, without an immediate connection to other events. For example, in (40), the individual is asked how often he visits Moscow. His visits to Moscow area are expressed as a part of the individual's experience. There is no coordinated event the person is influencing or is influenced by:

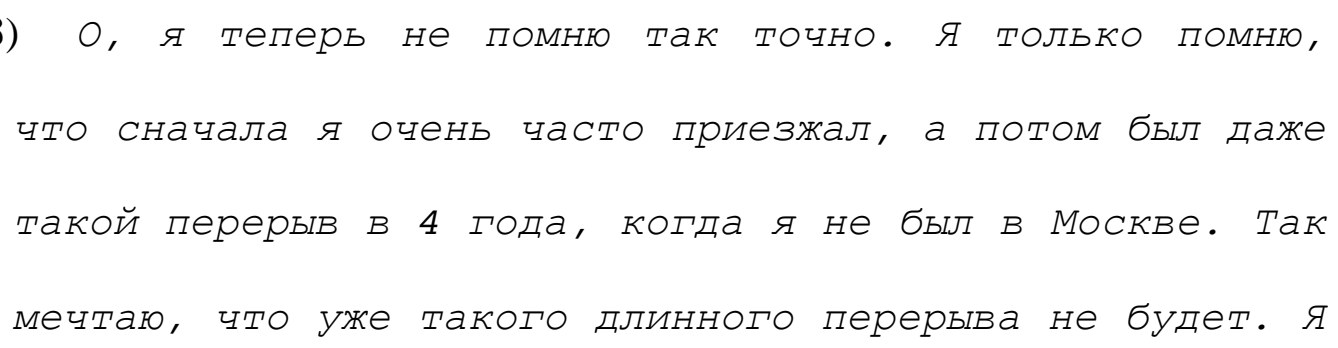




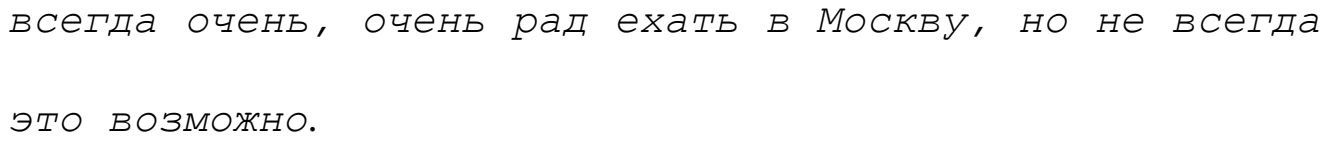

The period absence in (40) above is also cohesive, since the utterance is centered on one, first-person individual. Sometimes an individual feature of absence is needed to explain certain peculiarities or manner and reactions:

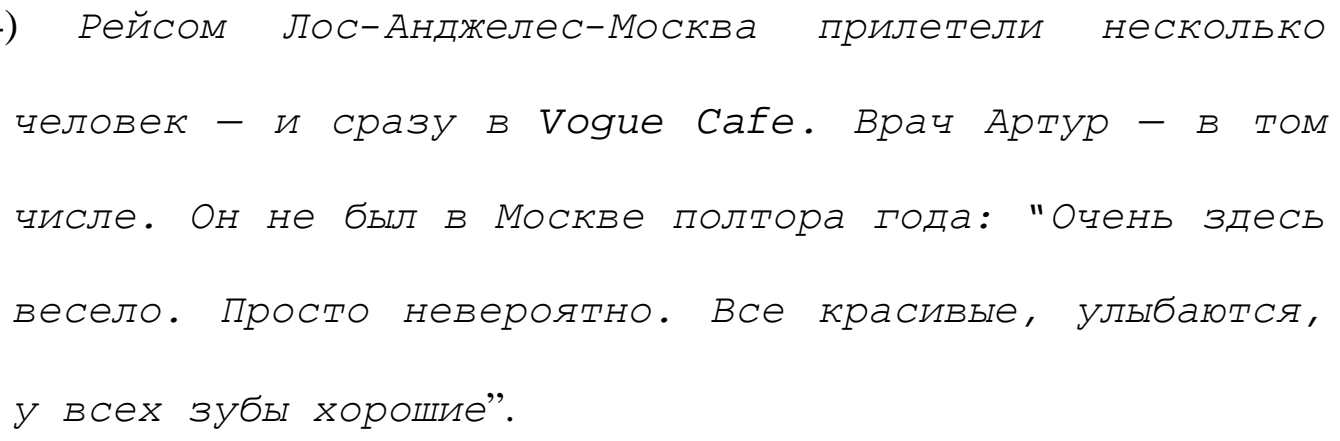

Part of the description of Arthur is that he is a doctor/dentist and wasn't in Moscow for 1.5 years. This is to explain his fascination with the happy Muscovites and their healthy teeth.

In some instances, the experience of absence does indeed occur at the same time as other events. But the events are not coordinated in the same sense as is the case with GACs. There is no pattern of influences between the individual and the situation. Most often, the individual makes an observation regarding his or her state of knowledge: the individual's absence affected his/her state of knowledge or thought processes, but there is no influence on the events or other individuals by this person. The absence and the 
subsequent lack of knowledge connect only to the individual. In contrast with the NS coordinated semantic templates, the GS presupposes a mutual interaction between the individual and the events that transpired in the locus during his/her absence.

A subcategory of the state of knowledge semantic template is the detached observation of the coordinated situation: the individual notices that things have happened while he/she was away, but the observation is detached in fashion, i.e. there is no influence by the individual on the developments in the locus, and there is no influence on the individual, except for the observation he/she makes.

The state of knowledge template appears in (42) where we find a second-person reference, and where the lack of information is a property of the individual, without any possible influence on the situation, or vice versa:

$$
\begin{aligned}
& \text { Если вы не были в москве или вообще в России, то } \\
& \text { может быть, вы не знаете, а вот другие коллеги ваши, } \\
& \text { наверное, знают, какая тяжелая моральная, } \\
& \text { психологическая ситуация была после взрывов в москве. }
\end{aligned}
$$

Stylistically, (42) is not a polite utterance, as the speaker forcefully focuses on his addressee's absence and subsequent lack of knowledge while contrasting them to the knowledge of others.

Similarly, example (43) falls into this pattern. Here a vampire woman does not have knowledge of current hotels in Moscow, since she has not been in Russia for 90 
years. She doesn't have the knowledge needed; however, this has no repercussions for the situation, but only for herself. The NAC here may be understood as an explanatory aside on the part of speaker.

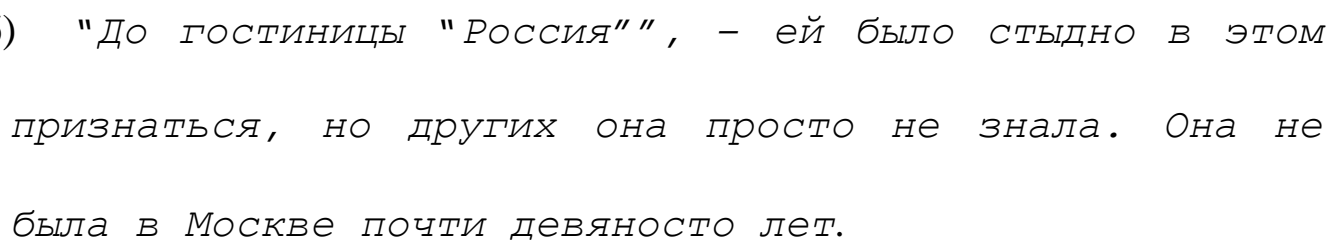

Detached observation is exemplified by (44), a personal narrative of an individual who was fired from work during the late Soviet times and of his subsequent adventurous career in business (with anecdotes from personal experience).

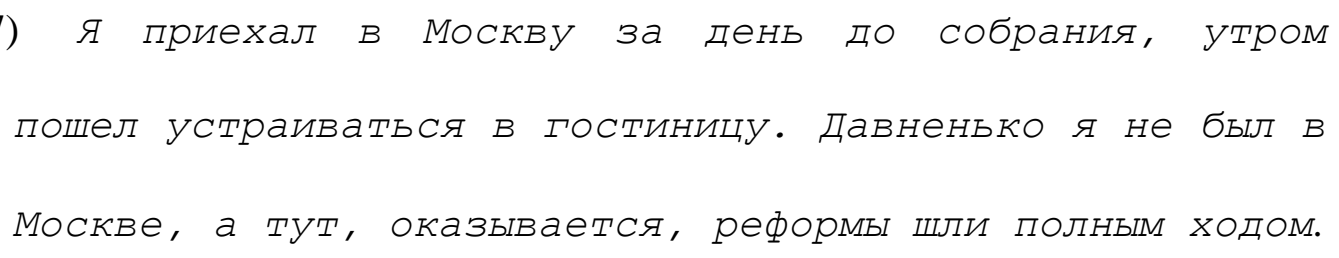

The example above also is cohesive, as the whole narrative is built around this individual.

Examples that combine text cohesion with individual experience are especially prominent in first-person narratives. In such narratives often the texts are built around the first-person reference, and the world is perceived through the individual's domain of experience. One such example is (45), where a soldier writes his last letters from the front line. The text focuses on the individual's perceptions, feelings, regrets; these are contained within the domain of the speaker's experience; the absence has no bearing on the coordinated events - the Rimsky-Korsakov and Chekhov jubilees. 


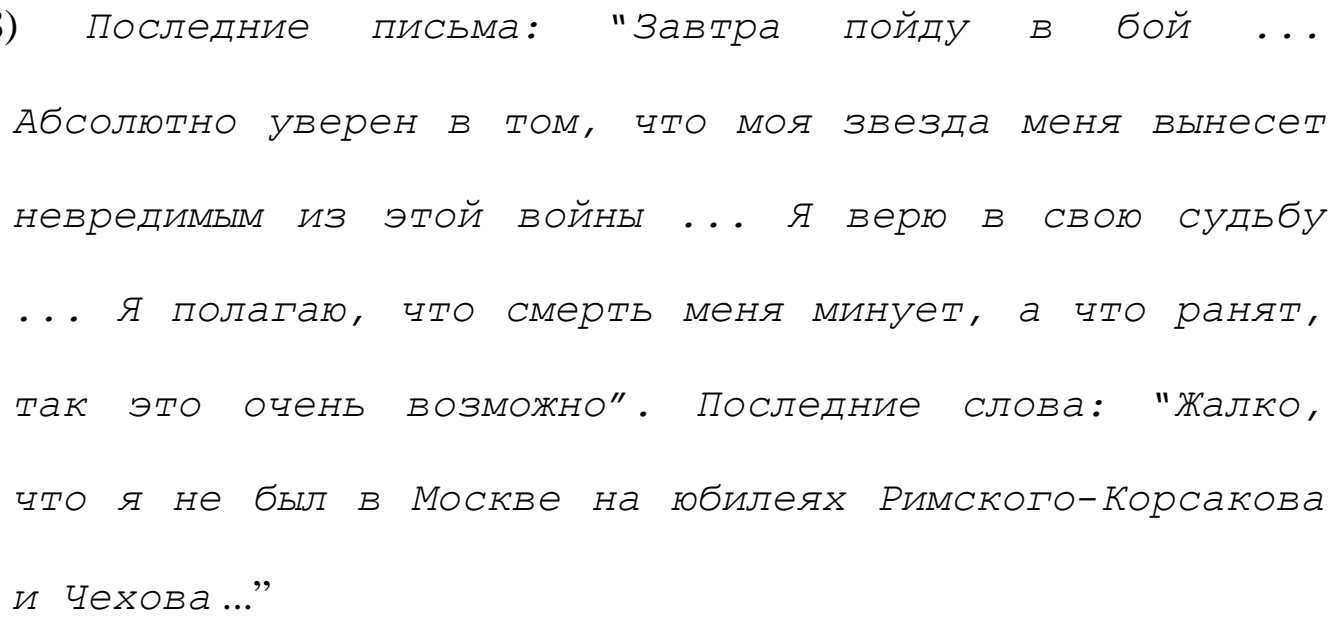

\subsection{Additional nominative factors}

\subsubsection{Syntactic Parallelism}

In some instances the choice of nominative case is prompted by syntactic parallelism with a positive clause. This can happen even in those instances when genitive would be expected, as in the following example (46), where existential locus and semantics would normally require genitive:

(49) То ли был, то ли не был на свете один цыганкузнец.

Syntactic parallelism can also figure as one of the factors that contribute to the choice of nominative. The following example from fan fiction writing features syntactic parallelism, but also cohesive focusing in the absentee and his experiences outside of his house: 


"я дома, дома", - повторял я себе. "Дома, за
компьютером. Сейчас сработает таймер, и я я
рассыплюсь для окружаюших снопом таюих искр, сейчас
кончится этот морок ... Скорей бы попасть домой ..."
[...] но я не был дома. Я понял это сразу: я
все так же стоял на улице, прислонясь к к стене
дома.

An additional example (48) shows that syntactic parallelism can operate even for nonanimate subjects, which would not be able to take the nominative case under other circumstances:

$$
\begin{aligned}
& \text { Именно в этот момент, произнеся эти слова, он } \\
& \text { почувствовал в себе обостренную расчетливость, } \\
& \text { умение сосредоточиваться на никому не ведомых } \\
& \text { событиях, на тех, которые вроде бы были, но тем не } \\
& \text { менее - не были. (Анатолий Азольский. Лопушок) }
\end{aligned}
$$

\subsubsection{Translation}

The choice of nominative is statistically more frequent in translated texts. This choice is often made in utterances where genitive marking would be expected due to a variety of syntactic and semantic factors - sometimes contributing to the general feeling of "awkwardness" of a translation. The following example from the translation of Simon 
Clark's Aldebaran combines such genitive factors as absence coordinated with an event, absence at the moment of death, complex pattern of influences (the absentee thinks he could have prevented the death), emotional attitude (feelings of guilt and regret, etc):

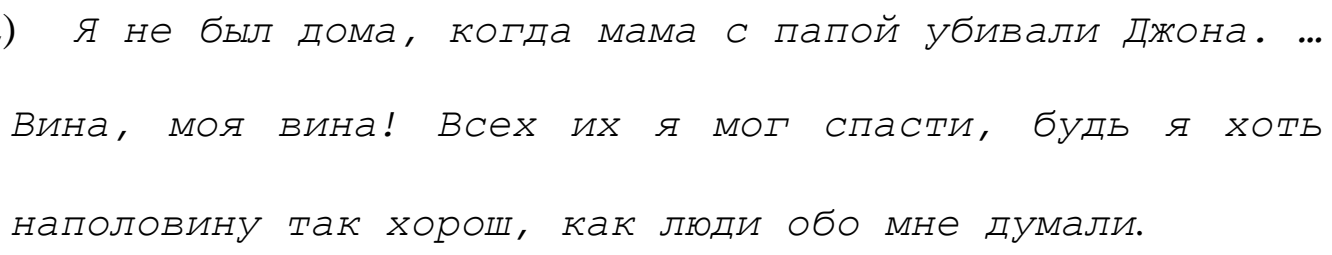

This example is, in fact, similar to (11), where the speaker regrets being absent at the moment of suicide. The genitive in (11) is expected, the choice of nominative in (48) is made plausible by the translated nature of the text.

\section{Concluding remarks}

In the analysis above I have examined multiple factors that can play a role in the speaker's choice of case, among them clause-level parameters - individuation of absentee, the nature of a locus (individuated, existential, geographical label, etc.), specification of timeframe (coordination, duration); text-level phenomena such as focusing and cohesion; emotional attitude and point of view; common semantic templates; and some additional phenomena such as syntactic parallelism and peculiarities of a translated text. Some of those factors may strongly influence the choice of case: for example, a clause with a geographical label (на море, на Днепре) and a timeframe of duration will usually combine with a nominative marking of the absentee. A clause with an existential locus в мире, на свете, на земле will predictably show a 
referential subject in genitive. However, other choices can never be excluded: a clause with an existential locus can have a nominative referential subject due to syntactic parallelism (46), or in order to create an unusual semantic meaning and to focus on the individual (35). A clause with a geographical label can have the referential subject marked genitive when factors such as coordination on the timeframe and emotional expression of regret come into play (34). Coordination is obligatory for GACs, but shows up also in nominative clauses (38), (45) where nominative is triggered by such factors as cohesive focusing on the absentee and his/her individual properties. Time specification of duration is characteristic of NACs, but it can also appear in genitive clauses due to other factors such as coordination, complex pattern of influences (9), semantic templates such as making apologies or explaining current state of events (24), emotional attitude etc. We have also seen that a presence of an "observer", i.e. an additional individual in a situation of presence in the locus, is not by itself sufficient to prompt use of the genitive - it is a question of conflicting points of view and processes of cohesive focusing (as discussed in section 2.1.2.2), often combined with other factors such emotional attitude, semantic considerations etc.

It is therefore crucial to use a multifactor approach to case choice when examining absence constructions. Many of those factors appear more frequently in GACs or NACs, and tend to cluster together into a "predictably nominative" or "predictably genitive" choice. If a rule of thumb is needed, one could say that genitive choice is about coordination and interaction with other elements in the text, while nominative choice is 
about focusing on the absentee and his/her properties. But such simplification will not be very useful when trying to understand how choices operate in real life and in real examples. It is important to remember that while factors tend to combine in certain predictable ways, the speaker is free to construct other combinations and to create nonstandard semantics with the factors available to him/her. The multifactor approach accounts for both fixed and flexible choices.

\section{NOTES}

I would like to express my gratitude to Profs. Alan Timberlake and Johanna Nichols of UC Berkeley for their support and essential critical commentary on all stages of this project.

+ Since the literature on the topic is quite extensive, I will not offer a full survey of literature here. A good overview of the constructions and discussion can be found in Borschev and Partee (2002), and Timberlake (2004).

This word order change is, of course, not obligatory or even statistically predominant in genitive negated clauses. Discussion of word order is, unfortunately, outside the scope of this paper. 


\section{REFERENCES}

Падучева, Е. В.: 1992, 'О семантическом подходе к синтаксису и генитивном субъекте глагола Быть', Russian Linguistics 16, 53-63.

Падучева, Е. В.: 1993, 'Говорящий как наблюдатель: об одной возможности применения лингвистики в поэтике', Известия Академии наук, Серия литературы и языка 52/3, $33-44$.

Падучева, Е. В.: 1997, 'Родительный субъекта в отрицательном предложении: синтаксис или семантика?', Вопросы языкознания, вып. 2, 101-16.

Babby, L. H.: 1980, Existential Sentences and Negation In Russian, Ann Arbor. 
Borschev, V.: 1999, 'Semantic types and the Russian genitive modifier construction', Annual Workshop on Formal Approaches to Slavic Linguistics: The Seattle Meeting, 1998, K. Dziwirek and H. Coats (eds.), 39-57.

Borschev, V., Partee, B. H.: 1998, 'Formal and lexical semantics and the genitive in negated existential sentences in Russian', Annual Workshop on Formal Approaches to Slavic Linguistics: The Connecticut Meeting, 1997, Z. Boskovic, S. Franks, 75-96.

Borschev, V., Partee, B. H.: 2002. 'The Russian genitive of negation in existential sentences: the role of theme-rheme structure reconsidered', Travaux du Cercle Linguistique de Prague n.s./Prague Linguistic Circle Papers, Vol. 4, E. Hajicova, P. Sgall (eds.), 185-250.

Chvany, C. V.: 1996, Selected Essays of Catherine V. Chvany, O. T. Yokoyama, E. Klenin (eds.), Columbus, Ohio.

Timberlake, A.: 2004, A Reference Grammar Of Russian, Cambridge, U.K.- New York.

University of California, Berkeley

renee_p@berkeley.edu 